Doses of BCV less than or equal to $100 \mu \mathrm{g} / \mathrm{ml}$ (approximately $3 \times 10^{-7} \mathrm{M} a$-toxin) shifted the ACh dose-response curves of Mercenaria, Chione, Mya, Mytilus and Rangia to the right by 2-5 orders of magnitude; this inhibition was rapidly reversed by washing. The $\mathrm{ACh}$ sensitivities of Crassostrea hearts, in contrast, were relatively unaffected by BCV. When the experiment was repeated on Mercenaria, Rangia and Crassostrea hearts with 4-ketoamyltrimethylammonium chloride $(4 \mathrm{~K}$; an $\mathrm{ACh}$ analog lacking the esteratic linkage hydrolyzed by $\mathrm{AChE}$ ) as agonist, $\mathrm{BCV}$ had no effect on the response sensitivities of any of the 3 (table). Since BCV contains $A \mathrm{ChE}^{13}$, the lowered responsiveness of most of these hearts probably resulted from the presence of the enzyme in the bath rather than from any effect of the $a$-toxins on the receptors. The high endogenous AChE activity of Crassostrea hearts ${ }^{8}$ explains both the ineffective- ness of BCV in this species and the greater sensitivity of oyster hearts to $4 \mathrm{~K}$ as compared to $\mathrm{ACh}$

Crude BCV also had an excitatory effect of its own on all of the myocardia tested. Excitation could not have been produced by 5 -hydroxytryptamine $(5-\mathrm{HT})$ in the venom since the response was not blocked by methysergide (a potent 5-HT antagonist). And it could not have been due to $A C h$ because of the AChE in the venom ${ }^{13}$. The excitation is not unexpected since, in addition to short a-toxins, the crude venom contains an arsenal of other polypeptides and enzymes ${ }^{14}$

In conclusion, these elapid $a$-toxins lack any effect on the nicotinic ACh receptors of bivalve mollusc hearts. This is yet another example of the pharmacological heterogeneity of nicotinic receptors in general $9,13,15,16$.
1 Acknowledgments. This work was supported by N.I.H. grant HL-09283 to M.J.G.; it is contribution No. 102 from the Tallahassee, Sopchoppy and Gulf Coast Marine Biological Association

2 M.J. Greenberg, Comp. Biochem. Physiol. 14, 573 (1965),

3 M.J. Greenberg, Experientia 15, 250 (1969).

4 M.J. Greenberg, Comp. Biochem. Physiol. 33, 259 (1970)

5 J.P. Changeux, M. Kasai and C.Y. Lee, Proc. nat. Acad. Sci. USA 67, 1241 (1970)

6 C. L. Prosser, Biol. Bull., Woods Hole 78, 92 (1940).

7 G.A. Cotrell, B. Powell and M. Stanton, Br. J. Pharmac. 40, 866 (1970).
8 T. Roop and M.J. Greenberg, J. exp. Zool. 198, 121 (1976).

9 S. Bursztajn and M. Gershon, J. Physiol., Lond. 269, 17 (1977)

10 S.J. Burden, H.C. Hartzell and D. Yoshikami, Proc. nat. Acad. Sci. USA 72, 3245 (1975).

11 C.Y. Lee, Ann. Rev. Pharm. 12, 265 (1972).

12 C.C. Chang, T.T. Chen and S.T. Chuang, Br. J. Pharmac. 47, 147 (1973).

13 J.S. Kehoe, R. Sealock and C. Bon, Brain Res. 107, 527 (1976).

14 C. Bon and J.P. Changeux, Eur. J. Biochem. 74, 31 (1977)

15 W. Shain, L.A. Greene, D.O. Carpenter, A. J. Stykowski and Z. Vogel, Brain Res. 72, 225 (1974)

16 A.C. Szczepaniak, J. Physiol., Lond. 24, 55P (1974).

\title{
Effect of gum Arabic on aminopyrine demethylation in rats
}

\author{
W.K. Lutz, E. Brändle and G. Zbinden
}

Institute of Toxicology, Federal Institute of Technology and University of Zurich, Schorenstrasse 16, CH-8603 Schwerzenbach (Switzerland), 3 May 1978

Summary. Stimulation of aminopyrine demethylation induced in rats by oral or i.p. administration of phenobarbital was partially inhibited in animals receiving daily treatments of $2 \times 200 \mathrm{mg} / \mathrm{kg}$ gum Arabic p.o.

Earlier studies in this laboratory have shown that repeated oral administration of commonly used suspending agents (gum Arabic, gum Tragacanth, methylcellulose and carboxymethylcellulose) affected the function of heart and liver mitochondria and mixed function oxidases in the liver of small laboratory animals ${ }^{1,2}$. For example, 40 and 200 $\mathrm{mg} / \mathrm{kg}$ gum Arabic given twice daily on 5 days per week to rats caused uncoupling of oxidative phosphorylation of mitochondria isolated from heart and liver, and a progressive inhibition of 2- and 4-biphenylhydroxylase in liver microsomes. In all these studies, ex vivo procedures were used. It was, therefore, interesting to investigate whether comparable biochemical effects of gum Arabic could also be demonstrated in a living animal. For this purpose, the expiratory measurement of maximal aminopyrine demethylation ${ }^{3}$ promised to be a suitable approach.

Material and methods. The in vivo demethylation of 4dimethyl $\left({ }^{14} \mathrm{C}\right.$ )aminoantipyrine (DAA, The Radiochemical Centre, Amersham, England, sp. act. $15.6 \mathrm{mCi} / \mathrm{mmole}$ ) was measured by trapping expired ${ }^{14} \mathrm{CO}_{2}$ from an inhalation chamber. The method of Lauterburg and Bircher ${ }^{3}$ was used with the following modifications: the air drawn through the inhalation chamber ( 21 desiccator) was dried with silica gel and freed from $\mathrm{CO}_{2}$ with solid $\mathrm{KOH} .50 \mu \mathrm{Ci}$ DAA were dissolved in $20 \mathrm{ml} 0.9 \% \mathrm{NaCl} .100 \mu \mathrm{l}$ of this solution $(0.25 \mu \mathrm{Ci})$ were injected under light ether anesthesia into the subclavial vein of female rats (ZUR SIV -Z strain, initial weight $152-180 \mathrm{~g}$ ). The expired ${ }^{14} \mathrm{CO}_{2}$ was collected in 8min fractions for $40 \mathrm{~min}$. The fraction containing the highest radioactivity was taken to calculate the peak demethylation rate. It was expressed as fraction of the total DAA dose expired as $\mathrm{CO}_{2}$ per min. This measurement was made for each individual rat 1 day before and after treatment, exactly at the same time of day. In the 3rd experiment, an additional measurement was made on the last day of a pretreatment phase. The relative induction of demethylase activity was calculated by dividing the peak rate after treatment by the peak rate before treatment. 1st experiment: 2 groups of 2 rats received $0.2 \mathrm{ml} / 100 \mathrm{~g} \mathrm{~b}$. wt of a $10 \%(w / v)$ aqueous suspension of gum Arabic (USP, Sigma Chemical Co., St. Louis, Mo.) by gavage at $09.00 \mathrm{~h}$ and $17.00 \mathrm{~h}$ on 3 consecutive days. A 3rd group received equal volumes of water. Phenobarbital (PB), University Hospital-Pharmacy, Zurich) was dissolved in water and given for the same 3 days at $17.00 \mathrm{~h}$ by gavage at a dose of $100 \mathrm{mg} / \mathrm{kg}$ to 1 group treated with gum Arabic and to the control group.

2nd experiment: 2 groups of 4 rats received gum Arabic as 
Effect of gum Arabic on PB-induced DAA demethylation

\begin{tabular}{|c|c|c|c|c|c|c|c|c|c|}
\hline \multirow[t]{2}{*}{ Experiment } & \multirow[t]{2}{*}{ Parameter" } & \multicolumn{2}{|c|}{$\begin{array}{l}\text { Gum } \\
\text { Arabic }+0.9 \% \mathrm{NaCl}\end{array}$} & \multicolumn{2}{|c|}{ Gum Arabic + PB } & \multicolumn{2}{|c|}{ Water $+0.9 \% \mathrm{NaCl}$} & \multicolumn{2}{|l|}{ Water+PB } \\
\hline & & $\begin{array}{l}\text { Before } \\
\text { treatment }\end{array}$ & $\begin{array}{l}\text { After } \\
\text { treatment }\end{array}$ & $\begin{array}{l}\text { Before } \\
\text { treatment }\end{array}$ & $\begin{array}{l}\text { After } \\
\text { treatment }\end{array}$ & $\begin{array}{l}\text { Before } \\
\text { treatment }\end{array}$ & $\begin{array}{l}\text { After } \\
\text { treatment }\end{array}$ & $\begin{array}{l}\text { Beforc } \\
\text { treatment }\end{array}$ & $\begin{array}{l}\text { After } \\
\text { treatmen }\end{array}$ \\
\hline I & $\begin{array}{l}\text { Maximal demethylation rate } \\
\text { Relative induction }(n=2)\end{array}$ & $\begin{array}{l}0.389 \\
0.99 \pm 0.25\end{array}$ & 0.385 & $\begin{array}{l}0.395 \\
1.91 \pm 0.11^{8}\end{array}$ & 0.747 & - & - & $\begin{array}{l}0.406 \\
2.65 \pm 0.16^{8}\end{array}$ & $5^{a}$ \\
\hline II & $\begin{array}{l}\text { Maximal demethylation rate } \\
\text { Relative induction }(n=4)\end{array}$ & $\begin{array}{l}0.401 \\
1.03 \pm 0.14\end{array}$ & 0.411 & $\begin{array}{l}0.394 \\
1.80 \pm 0.50\end{array}$ & 0.668 & - & - & $\begin{array}{l}0.331 \\
2.35 \pm 0.31^{b}\end{array}$ & $0^{0.761}$ \\
\hline $\begin{array}{l}\text { III Pre- } \\
\text { treatment } \\
\text { phase (gum } \\
\text { Arabic only) }\end{array}$ & $\begin{array}{l}\text { Maximal demethylation rate } \\
\text { Relative induction }(n=8)\end{array}$ & $\begin{array}{l}0.479 \\
0.96 \pm 0.22\end{array}$ & 0.447 & & & $\begin{array}{l}0.478 \\
0.91 \pm 0.11\end{array}$ & 0.432 & & \\
\hline $\begin{array}{l}\text { III Treat- } \\
\text { ment phase }\end{array}$ & $\begin{array}{l}\text { Maximal demethylation rate } \\
\text { Relative induction }(n=4)\end{array}$ & $\begin{array}{l}0.474 \\
0.92 \pm 0.17\end{array}$ & 4.29 & $\begin{array}{l}0.420 \\
1.62 \pm 0.25 \mathrm{c}\end{array}$ & 6.79 & $\begin{array}{l}0.462 \\
1.04 \pm 0.10\end{array}$ & 0.482 & $\begin{array}{l}0.411 \\
2.16 \pm 0.65^{c}\end{array}$ & 0.868 \\
\hline
\end{tabular}

* Maximal demethylation rate, arithmetic mean of group, expressed in percent of DAA dose expired per min in the form of ${ }^{14} \mathrm{CO}_{2}$ Relative induction rate, arithmetic mean of individual inductions \pm 1 SD. $n$, Number of animals per group.

Significant difference in demethylase induction by PB between gum Arabic-treated and water-treated animals calculated according to Student's t-test (one-sided). ${ }^{a} \mathrm{p}=0.015,{ }^{\mathrm{b}} \mathrm{p}=0.054,{ }^{\mathrm{c}} \mathrm{p}=0.086$.

indicated above on 4 consecutive days. A control group was administered equal volumes of water. At $17.00 \mathrm{~h}$ of each day, rats of 1 gum Arabic-treated and the control group were injected i.p. with $75 \mathrm{mg} / \mathrm{kg} \mathrm{PB}$ in $0.9 \% \mathrm{NaCl}$. The 2nd group treated with gum Arabic received equal volumes of $0.9 \% \mathrm{NaCl}$ solution i.p.

3rd experiment: 2 groups of 4 rats received gum Arabic as indicated above on 3 consecutive days. 2 control groups were treated with equal volumes of water. After this pretreatment phase oral gum Arabic and water administration was continued for additional 4 days. 1 gum Arabictreated and 1 control group were injected daily with $75 \mathrm{mg} / \mathrm{kg}$ PB i.p. The 2nd gum Arabic and control group received injections of equal volumes of saline.

Results. Repeated administration of gum Arabic or water had no effect on DAA demethylation (table). In all experiments, the peak demethylation rates were almost identical before and after treatment. Peak demethylation rates more than doubled in water-treated rats after 3-4 oral or parenteral doses of PB. In rats receiving gum Arabic, however, induction by PB of demethylase activity was consistently reduced.

Discussion. Gum Arabic, a dried exsudation of various Acacia plants, is widely used as thickener and emulsifier in foods and drugs. Toxicological and metabolic studies of this product are scarce. Nevertheless, in view of its traditional uses and its apparent complete digestion in the gut the FAO/WHO Expert Committee on Food Additives has not imposed any limitation on its consumption by the human population.

Animal experiments show that gum Arabic cannot be regarded as a biologically inert material. In the rat, it caused a dose-dependent and cumulative inhibition of liver biphenyl hydroxylation which was not accompanied by a reduction in cytochrome P-450 levels. Similar observations were made in mice and hamsters, although in these species the enzyme inhibition was transient. In mice a slight decrease in liver cytochrome P-450 coincided with the enzyme inhibition ${ }^{1,2}$. Repeated administration of gum Arabic to rats did not affect the in vivo activity of aminopyrine demethylase. However, the induction of this enzyme by oral and parenteral PB was partially inhibited in rats receiving gum Arabic per os. A similar observation was made with another vegetable gum, gum Tragacanth: single oral or parenteral administrations to mice did not affect hexobarbital sleeping time, but the shortening of hexobarbital narcosis induced by urethan or PB was blocked by i.p. injections of the gum ${ }^{6}$. In contrast to our observations, no effect on hexobarbital sleeping time was seen after orally administered gum Tragacanth. However, only 1 dose of the gum was given. According to our experience as many as 32 oral doses of gum Tragacanth must be administered to rats to induce a moderate inhibition of biphenyl hydroxylase in liver microsomes ${ }^{1}$. Thus, the failure of Fujimoto $^{6}$ to demonstrate an oral effect may be due to insufficient dosing.

The inhibiting effect of gum Arabic on liver mixed function oxidases cannot be explained readily by the use of conventional enzyme kinetics. Recent studies have shown the multiple enzyme nature of the mixed function oxidase reactions ${ }^{7}$. A large number of synthetic and naturally occurring substances were found to inhibit the degradation of foreign compounds that are substrates of these enzymes. Many of these inhibitors act through a tight binding of an intermediate or reaction product to the enzyme, a process which is species-dependent. Pretreatment of the animals with PB not only increases cytochrome P-450 content of the liver, but also activates the complex formation and thus the enzyme-inhibiting activity with the intermediates ${ }^{8}$. Thus, it might be worth-while to investigate whether the enzymeinhibiting action of gum Arabic and gum Tragacanth are also caused by metabolic intermediate-enzyme complexes. It should also be noted that the endoplasmic reticulum is not the only cell organelle affected by gum Arabic. In earlier experiments, a striking effect was also demonstrated on the function of heart and liver mitochondria ${ }^{1,2}$. The possibility that these derangements of the intracellular biochemical equilibrium is due to a nonspecific action on membranes and the function of membrane-bound enzymes must therefore also be considered.

1 E. Bachmann, E. Weber, M. Post and G. Zbinden, Pharmacology 17,39 (1978).

2 E. Bachmann and G. Zbinden, Archs Tox. suppl. I, 83 (1978).

3 B. H. Lauterburg and J. Bircher, J. Pharmac. exp. Ther. 196, 501 (1976):

4 FAO-WHO Expert Committee on Food Additives, FAO Nutrition Meetings, Report Series, No. 46A, 97 (1969).

5 FAO-WHO Expert Committee on Food Additives, WHO Food Additive Series No.5, 316 (1974).

6 J.M. Fujimoto and G.L. Plaa, J. Pharmac. exp. Ther. 131, 282 (1961).

7 I. Björkhem, Pharmac. Ther. A, 1, 327 (1977).

8 M.R. Franklin, Pharmac. Ther. A, 2, 227 (1977). 